\title{
History of Numbers and Fractions and Arithmetic Calculations in the Tamil Region: Some Observations
}

\author{
V. Selvakumar* \\ Department of Epigraphy and Archaeology, Tamil University, Thanjavur - 613010, \\ India; selvakumarodi@gmail.com
}

\begin{abstract}
The Tamil inscriptions of the medieval period provide a very detailed account on the land measures in minute fractions. In the Medieval period, the villages were completely measured and documented, especially in the fertile Kāviri delta and other cultivable areas, for accurately assessing tax. The land measurements are discussed in terms of various units of measures, especially miniscule fractions, and the calculations of taxable and tax-free areas are also specified in some of the inscriptions. This paper presents a preliminary account of the fractions, numbers and arithmetic calculations found in the Medieval Tamil inscriptions.
\end{abstract}

Keywords: Arithmetic Calculation, History of Science, Land Administration, Medieval Measurements, Tamil Fractions

\section{Introduction}

In the study of history of science, the development and use of concepts related numbers, fractions and arithmetic calculations form an important component. There is a lot scope to research on the history of science and traditional knowledge systems in India, and when we look at this subject objectively, without any emotional attachment and pride, there is much to learn from these traditional concepts of science, which can be very useful for academic understanding as well as for imparting cognitive skills among the youngsters as part of the contemporary education. In the area of history of numbers, arithmetic calculations and mathematics in India, much research has been done [1, 6], and in this paper, I present a preliminary survey of the numbers, fractions and arithmetic calculations that were used in Tamil region in the historical period.

Simple arithmetic calculations were used for day-today accounting and for the assessment of land revenue during the medieval period. The Tamil inscriptions, literature and palm-leaf manuscripts serve as important sources for understanding the fractions, numbers and arithmetic calculations. Specific symbols or markers were used to identify these fractions, apart from specific words. The land measurement, weight and volume measurements of various materials donated to the temple are also listed out in minute detail, in the inscriptions. In the medieval period, there were accountants who calculated the land area and assessed them for tax, and maintained detailed accounts of the lands and taxes to be collected.

The use of numbers or counting, perhaps began in the prehistoric period, when people calculated the number of people, fruits and other countable elements that were essential for their day-to-day activities. Nowadays people tend to visualize the figures such as 10, 100, 200 and 1000 as complete; but, the perception of these decimal based numbers as complete entities is nothing, but our own imagination. The number of body parts such as head, eyes, fingers that humans have perhaps helped in counting numbers in the very early stages of history. In the Indian tradition, the earliest reference to numbers comes from the Védic texts; many other early Indian texts have information on large numbers (e.g. Vālmīki Rāmāyana mentions about very high numbers $[6,11]$ (e.g. $\left.10^{57}\right)$. Symbols for

\section{*Author for correspondence}

Note: The author acknowledges the Indian National Science Academy for the financial support to pursue this research. 
numerals are also found in the Asokan inscriptions, and also in the Nānéghat inscription [6]. It appears that the decimal system might have developed in India from the Harappan times [6]. Different systems were used in India for denoting numbers in the historical period. In the Bhutta Samkya system, numbers were identified by objects or ideas. The Katapayati system seems to have been developed by Vararuci, an astronomer and mathematician from Kérala, belonging to the medieval period. In this method, different letters are assigned numerical values, and words or slōkās are formed; for example, "nanajnanapragalbhah" in this system means the figure of $43,20,000$ [11].

\section{Numbers in Tamil}

Different symbols were used in Tamil Nadu for denoting numbers. The Brahmi inscriptions have evidence for the use of numbers, according to Iravatham Mahadevan [9]. At Azhakankulam (Alakankulam), the Early Historic site, numerals are found on pottery. However, the numbers, fractions and arithmetic calculations are found more frequently in the inscriptions from the medieval times. The medieval inscriptions give the numbers as figures and sometimes also as text, perhaps to make sure no error appears in their reading and interpretation. The Tamil work of Kanakkatikāram by Kāri Nāyanār is an important medieval work on mathematics [8]. This tradition of using Tamil numerals has continued to this day, although in the limited circles of Tamil studies and among Tamil scholars during the modern (colonial) period, when the so called Arabic numerals were introduced. As a result of the change in the use of numerals during the modern period, nowadays many people cannot understand the traditional Tamil numerals.

The traditional Tamil numerals of the contemporary period very much resemble the Tamil letters/characters that have specific phonetic value. For example, the Tamil letter அ (a) stands for the number 8 and வ stands for quarter (1/4). Kālamégappulavar, a famous poet of the modern period, made a pun, using the symbols of letters " 8 " and "1/4." In a poem, he mentions about "8 1/4 (ețtékāl) lațcanamé" which means "avalatcanam," (=ugly).

The word "en' in Tamil denotes numeral in a general sense and it also denotes the number eight. Perhaps, eight was seen as a complete or the largest number in the Tamil tradition. In Tamil system, the numbers 1 to 8 are mentioned as individual numbers, while 9 is mentioned as one less than 10. Earlier the term tondu was used to refer to 9. The term "onpatu" for nine, actually means one less than 10. Similarly, the numbers 90 and 900 are also mentioned in relation to 100 and 1000 , respectively. Based on these features, it can be argued that eight-based numeral system was probably used in the Tamil region in the early period. However, this proposition needs to be investigated further.

The manner in which numbers are mentioned in Tamil has a pattern much different from Sanskrit. "Eleven" is written in Tamil as 'ten plus one.' However, in Sanskrit, "one" is mentioned first and then ten, e.g. ékädasi, 11. The French language has a system of writing numbers, which is similar to Tamil.

\section{Tamil Numerals and their Symbols}

Tamil numerals and symbols are mentioned in the Tamil Inscriptions and they are also found in the palm-leaf manuscripts. In the inscriptions, the numbers are mentioned in a specific pattern. There are separate symbols for 1 to 10 , 100 and 1000 , and these symbols are combined to covey a specific figure. There is no place value system here. The number 88 is conveyed with the symbols of " $8,10,8$," which means the first two figures have to be multiplied and the last figure has to be added. The number 800 was written as $8,100=$ then it has to be read as 800 . For example, Kali year 4820 would be written as 4,$1000 ; 8,100 ; 2,10=4820$ (without any punctuation in between). The numbers are placed as they spelled in Tamil language, twenty-four would be spelled as "irup attu nāngu" $=2,10,4$. Tamil inscriptions and manuscripts have the various symbols used for numbers, fractions and various land, weight and volume measures. Recently, Tamil Virtual Academy (TVA) under the control of Government of Tamil Nadu has created a document in register of the Unicode Consortium (UC) [22] (Table 1) for creating standard symbols for digital records.

\section{Fractions}

The knowledge of fraction is generally traced to the Védic period [21]; but there are chances for their use in the Harappan culture, since the Harappans were involved in extensive commercial activities. Fractions were frequently used in the medieval inscriptions of Tamil Nadu. The word arai in Tamil refers to half and interestingly, arai means waist part of the humans. The term $k \bar{a} l$ refers to leg in Tamil and perhaps, the term derived from the length of one portion of human leg. Mukkāl refers to $3 / 4$ and it written as three quarters. A few of the smaller fractions such as araikkāl $(1 / 8)$, araiyéaraikkāl $(1 / 16)$ are referred to as màkàni or vīsam. Mā refers to $1 / 20, k \bar{a} n i$ refers to $1 / 80$. Muñtiri refers to the fraction of $1 / 320$. However, Subrahmanian [20] lists 
Table 1. Numerals, fractions and their symbols

\begin{tabular}{|c|c|c|c|c|}
\hline Figures in Words & Numerals & Multiplication of & Symbol 1 & Symbol 2 TVA2014 \\
\hline $\bar{A}$ yiram & 1000 & & & \\
\hline 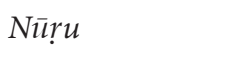 & 100 & & $n$ & \\
\hline Pattu & 10 & & $\omega$ & \\
\hline Onpatu & 9 & & fr & \\
\hline Etțu & 8 & & & \\
\hline ézhu & 7 & & & \\
\hline $\bar{A} r u$ & 6 & & $\pi$ & \\
\hline aintu & 5 & & & \\
\hline Nāngu & 4 & & & \\
\hline Mūnṛu & 3 & & & \\
\hline Iraṇdu & 2 & & 2 & \\
\hline Onṛu & 1 & & $\Phi$ & \\
\hline Mukkāl & $3 / 4$ & & 65 & க \\
\hline Arai & $\overline{\mathrm{o}}$ & & & \\
\hline Kāl & $1 / 4$ & & $\boldsymbol{y}$ & \\
\hline Nālumā & $1 / 5$ & $4 \times 1 / 20$ & & \\
\hline Araikkāl & $1 / 8$ & $1 / 4 \times \overline{0}$ & & வேு \\
\hline Irumā & $1 / 10$ & $2 \times 1 / 20$ & & $\stackrel{\infty}{\varrho}$ \\
\hline Mākani, vīsam & $1 / 16$ & $(1 / 20+1 / 80=5 / 80=1 / 16)$ & & \\
\hline Mummākāṇi & $3 / 16$ & $=3 / 16$ & $\boldsymbol{F}^{\mathbf{R}}$ & $\mathrm{I}_{2}$ \\
\hline Mummā & $3 / 20$ & $3 \times 1 / 20$ & & \\
\hline
\end{tabular}


$M \bar{a}$

Araivīsam

Araimā

Kālvīsam

Kāṇi

Mukkālvīsam

Mukkāṇi

Araikāṇi

Muñtiri

Araikāṇimuñtiri

Kìzh arai

Kìzh mukkāl

Kìzh kāl

Kìzh nālumā

Kìzh araikkāl

Kìzh irumā

Kìzh mummā

Kìzh vīsam

Kìzh orumā

Kīzh araimā

Kīzh mukkāni

Kīzh kāṇi

Kīzh araikkāṇi

Kīzh muñtiri

Immi -1 (Immimuñtiri)
$1 / 20$

$1 / 32$

$1 / 40$

$1 / 64$

$1 / 80$

$3 / 64$

$3 / 80$

$1 / 160$

$1 / 320$

$3 / 320$

$1 / 640$

$3 / 1280$

$1 / 1280$

$1 / 1600$

$1 / 2560$

$1 / 3200$

$3 / 6400$

$1 / 5120$

$1 / 6400$

$1 / 12800$

$3 / 25600$

$1 / 25600$

$1 / 51200$

$1 / 102400$

$1 / 1075200$
$\boldsymbol{U}$

Ey

$1 / 20 \times 1 / 4$

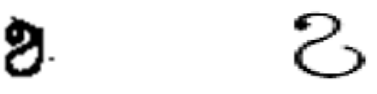

கூச

$1 / 320 \times \overline{0}$

ก

ர

ஹக

1/320x1/160

$1 / 320 \times 1 / 2$

$\not$

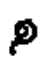

(Bharathiyar n.d 201-204)

(Bharathiyar n.d 201-204)

(Bharathiyar n.d 201-204)

(Bharathiyar n.d 201-204)

(Bharathiyar n.d 201-204)

(Bharathiyar n.d 201204)

(Bharathiyar n.d 201-204)

(Bharathiyar n.d 201204)

(Bharathiyar n.d 201-204)

(Bharathiyar n.d 201-204)

(Bharathiyar n.d 201-204) (araikkānì)

1/320 (muntiri) x 1/320 (muntiri)

1/102400 (kīzh muñtiri) $\mathrm{x}$ $1 / 10.5$
(Bharathiyar n.d 201-204)
(Bharathiyar n.d 201- 204)
8
ค

舟

(Bharathiyar n.d 201204)

(Bharathiyar n.d 201-204) 


\begin{tabular}{|c|c|c|c|}
\hline Immi -2 & $1 / 2150400$ & $\begin{array}{c}1 / 102400(k \bar{z} z h \text { munttiri }) \mathrm{x} \\
1 / 21\end{array}$ & Half of $i m m i 1$ \\
\hline Nunmuñtiri & $1 / 3225600$ & Immi $1 \times 1 / 3$ & \\
\hline Mummi & $1 / 23654400$ & $1 / 102400 \times 1 / 231$ & $\begin{array}{l}11 \text { times smaller than } \\
\text { immi } 2\end{array}$ \\
\hline Kìzh kīzh munttiri & $1 / 32768000$ & $1 / 320 \times 1 / 320 \times 1 / 320$ & \\
\hline$A n ̣ u$ & $1 / 165580800$ & $1 / 102400 \times 1 / 1617$ & $\begin{array}{l}\text { Seven times smaller than } \\
\text { mummi }\end{array}$ \\
\hline Guṇam & $1 / 1490227200$ & $1 / 102400 \times 1 / 14553$ & 9 times smaller than $a n u$ \\
\hline Kìzh kīzh kīzh munttiri & $1 / 10485760000$ & $1 / 320 \times 1 / 320 \times 1 / 320 \times 1 / 320$ & \\
\hline Vintam & $1 / 312947712000$ & $1 / 102400 \times 1 / 3056130$ & $\begin{array}{c}7 \text { times smaller than } \\
\text { Pāgam }\end{array}$ \\
\hline Nāgavintam & $1 / 5320111104000$ & $1 / 102400 \times 1 / 51954210$ & $\begin{array}{l}17 \text { times smaller than } \\
\text { vindham }\end{array}$ \\
\hline Sintai & $1 / 74481555456000$ & $1 / 102400 \times 1 / 727358940$ & 14 times nägavindham \\
\hline Katirmunai & $1 / 489631109120000$ & $1 / 102400 \times 1 / 14547178800$ & Muthukumar 2014 \\
\hline Kuralvalaippidi & $1 / 9585244364800000$ & & Muthukumar 2014 \\
\hline
\end{tabular}

the value of a kāni as $1 / 64$ and muntiri as $1 / 256$, and perhaps these fractions were based on a different calculation system, and probably a $m \bar{a}$ had a value of $1 / 16$ in this system. It might have been an early system or it was not widely used in Tamil Nadu and disappeared in the early medieval period. A similar term, kani used in Karnataka has a value of 1/64, according to Jagadish and Hegde [5]. In Andhra Pradesh too the term denotes the fraction of $1 / 64$.

Other minute fractions below muntiri (1/320) were mentioned as kizhh, which means below muntiri. Kìzharai means muntiri multiplied by arai $(1 / 320 \mathrm{x} \overline{\mathrm{O}}=1 / 640)$, and $k \bar{z} z h$ munttiri means $1 / 320 \times 1 / 320=1 / 102400$. Some of these fractions were represented by different symbols (Table 1). Fractions such as immi muntiri and nunmuntiri are found in Kanakkatikāram [8]. The Tanjāvūr Brihadhīswara temple inscriptions have references to minute fractions and the term $k \bar{i} z h$ has been referred to for such fractions below 1/320. A unit of the last series kīzh kīzh kīzh muntiri $\mathrm{x} 1 / 2$ is used in the Tanjāvūr temple inscription refers to the fraction of $1 / 5242,8800000$ of a véli, according to Venkayya [23]. Another inscription mentions about the fraction of 1/320x1/320x1/320x1/320x3/4x1/20 [7]. Subbarayalu [17, 18 ] has argued that such small fractions mentioned in the inscriptions for land areas resulted due to the reduction (madakku) of the area based on several parameters.

There are a lot of variations in the use of terms to denote the minute fractions and more detailed work is necessary on the original manuscripts, i.e. the primary sources. Many of the publications on numbers and fractions, available on the Internet, which were obviously collected from the early publications, list different figures for the Tamil words referring to fractions $[2,12,15]$. In the work Iniya Tamizh Ilakkanam by Cuddhananta Bharathiyar, kīzh araikkāni is listed as $1 / 512000$, perhaps this figure appears due to typographical error; but, the correct figure is 51200 , since it is $1 / 320 \times 1 / 160$ [3].

\section{Large Numbers}

Very large numbers were known to Indians. The ancient Indian texts have references to numbers as large as $10^{145}$ [4]. The large number of a ambal is mentoined in the 
Sangam Tamil texts. Although the text does not mention about the exact nature of the number, from other sources we know that it is a very large numer $\left(=10^{21}\right)$. Terms such as tamarai, āmbal, vellam are found in the Sangam texts and the Paripātal lists neytal, kuvalai, ämbal, sangam, kamalam and vellam (Paripātal 2: 12-15). The term kōti also occurs in Puranānūru (18: 5-6; 202:7). Several works such as Tolkāppiyam a nd Kambarāmāyanam mention about large numbers $[2,15]$. It appears that several terms were used for the numbers and there are variations in the defintion of numbers. For example, the term Mahapadma was used in ancient India for $10^{12}$ and $10^{34}$ [4].

\section{Technical Terms}

Several technical terms related to measurement of linear, area, volume and weights in the inscriptions. A few of the important terms are described as shown in Table 2.

\section{1 $\mathrm{K}^{1 / 2} \mathrm{l}$ or Danda}

Kōl or Danda refers to the measurement rods. They are found in various names in the inscriptions, and often their length is mentioned in terms of their size in cān or span, cubit or muzham or foot or ați. These measurement rods were used for building and temple constructions and also for land measurements. Different types of rods such as 16 span, 8 span, 22 span rods were used for measuring lands [14]. The span was defined as consisting of 12 angulam or viral. Twenty-four angulam or viral units formed a muzham or cubit. Sixteen-span rod was one of the commonly used measurement rods and the measurement rods of the medieval period are marked in the temples and on rock surfaces (Selvakumar 2014, 2015). Perhaps, each village had its own measurement rod and hence they were conveyed as "ivvurpați," (according the measurement rod system of this village) when the land was converted into the scheme of measurement of particular village.

Table 2. Large Numbers mentioned in Tamil/Indian system

\begin{tabular}{|c|c|c|c|}
\hline Number & Formula & Name & $\begin{array}{l}\text { As in Bhagavathy 2003/ } \\
\text { Shanmugan } 2006\end{array}$ \\
\hline 10 & $10^{1}$ & & Pattu \\
\hline 100 & $10^{2}$ & & Nuru \\
\hline 1000 & $10^{3}$ & & $\bar{A}$ yiram \\
\hline 10,000 & $10^{4}$ & & Pattāyiram \\
\hline 1,00000 & $10^{5}$ & & Nurāyiram \\
\hline 10,00000 & $10^{6}$ & & Pattulatcham \\
\hline 10000000 & $10^{7}$ & & Kōti \\
\hline 100000000 & $10^{8}$ & Pattukōti & Arputam [4] \\
\hline 1000000000 & $10^{9}$ & Tolluṇ & Nigararputam \\
\hline 10000000000 & $10^{10}$ & & Kumbam \\
\hline 100000000000 & $10^{11}$ & Arputam & Kanam/ Kanagam \\
\hline 1000000000000 & $10^{12}$ & Itiyam & Karpam \\
\hline 10000000000000 & $10^{13}$ & Nigararputam & Nikarpam \\
\hline 100000000000000 & $10^{14}$ & & Patumam \\
\hline 1000000000000000 & $10^{15}$ & Nelai/Karvam & Sangam \\
\hline 10000000000000000 & $10^{16}$ & & Vellam/Samutiram \\
\hline 100000000000000000 & $10^{17}$ & Sangam [4] & Anniyam/Antiyam \\
\hline 1000000000000000000 & $10^{18}$ & Ilanji & Mattiyam/Artam \\
\hline 10000000000000000000 & $10^{19}$ & Artam & Parartam \\
\hline 100000000000000000000 & $10^{20}$ & Vellam & Puriyam \\
\hline 1000000000000000000000 & $10^{21}$ & $\bar{A} m b a l /$ Puiyam & $\begin{array}{c}\text { Brammakarpam } \\
(k \bar{o} t i \text { kōti kōti= mukkōti) }\end{array}$ \\
\hline 10000000000000000000000000 & $10^{25}$ & Mukkōti & \\
\hline 10000000000000000000000000000000000000000000000000000000000 & $10^{57}$ & & Mahāyugam [11] \\
\hline
\end{tabular}




\subsection{Kuzhi}

Kuzhi is the Tamil term for pit and it has been used in the sense of area. An area covered by one $k \bar{o} l$ by one was called a kuzhi. It was commonly used as the basic measurement unit for area. One hundred kuzhi units formed one $m \bar{a}$ unit. 100 or 128 or even higher number of kuzhi units (128 and 256) formed one $m \bar{a}$, in some instances, and twenty $m \bar{a}$ units formed one Véli, the major area unit of measurement for land. This unit of measurement is still used in many parts of Tamil Nadu; more particularly in the Kāveri delta region. There is another term peruikuzhi found in the inscription perhaps refers to larger unit of kuzhi area.

\subsection{Madakku (Reduction)}

Madakku is a method of reduction of the area from one unit to another unit [7, 17-19]. Most probably, when an area measured by a smaller scale unit was converted on the basis of a larger scale, the process was called madakku. It was a kind of reduction process, in which a large area can be reduced to a small area.

\subsection{Virivu (Expansion)}

Virivu refers to expansion of a smaller area into a larger area on the basis of smaller measurement rod.

\section{Arithmetic Calculation in Inscriptions}

The inscriptions mention about the lands that had to be taxed and the area that had to be exempted from tax, such as temple lands, settlement areas cremation ground. Here two samples of arithmetic calculations from the inscriptions are analysed.

\subsection{Nallūr Inscription}

NallÂr in Pāpanāsam taluk of Tanjavur district has a Siva shrine called Kalyāna sundaréswarar temple. An inscription, issued during the 3rd regnal year of Rājarāja III (1218 CE) found in this temple [10] (Marxiya Gandhi and Ramachandran 2004:138, TNAD No 32/1995) mentions about the area of the land that was exchanged for another piece of land meant for the passage for carrying the dead body, which created a dispute in the village.

The area is mentioned as $2 k \bar{o} l$, in north-south, by $15 \% 3$ $+3 / 20$ (patinañjé mukkālé mūnṛu mā) on the east-west, and the total area was $313 / 4+1 / 20$ perunkuzhi or square kuzhi, in the inscription.

When we multiply the above numbers, we get

$$
\begin{aligned}
(15 \times 2)= & 30+(2 \times 3 / 4)=1.5+(2 \times 3 / 20)=6 / 20=313 / 4 \\
& +1 / 20
\end{aligned}
$$

Or $2 \times(63 / 4+3 / 20)$

$2 \times 315+3 / 20$

$2 \times 318 / 20=636 / 20=31+16 / 20=31+3 / 4+1 / 20$

The term perunkuzhi mentioned here, perhaps meant a larger measurement rod which was employed for measurement.

For the above mentioned piece of land, another land was given in exchange and its size was

$$
\begin{aligned}
& 81 / 4 \mathrm{kol} \text { by } 33 / 42 / 20 \mathrm{kol}=33 / 4 \times(15 / 4+2 / 20)=75+2 / \\
& 20=77 / 20 \\
& 33 / 4 \times 77 / 20=2541 / 80=31+61 / 80=31+3 / 4+1 / 80
\end{aligned}
$$

Actually the land given exchange for the original piece of land was slightly less and it is only 31 mukkāle kāni; however, it is mentioned as $313 / 4+1 m \bar{a}(1 / 20)$. Perhaps, they intentionally ignored the small variation in the land.

\subsection{Another Inscription from Nallūr}

Another inscription from the same temple issued in the $30^{\text {th }}$ year of Rājarāja III talks about the same issue and mentions about another land area (ARE 31/1995).

Here a piece of land is mentioned as $2 k \bar{o} l$ by $28 k \bar{o} l=$ 56 kuzhi.

\section{$28 \times 2=56$}

Here another tem uriya kuzhi is mentioned.

The area of 87.5 kuzhi is mentioned as uriya kuzhi for 56 $k u z h i$, which means an equivalent unit in another scheme of measurement. We can deduce the approximate variation in the expansion of the measurement rod here. The unit of $2 \mathrm{ko} l$ in one scheme becomes $2.5 \mathrm{k} \bar{l} \mathrm{l}$ in the new scheme and therefore $28 k \bar{o} l$ units become $35 k \bar{o} l$ units; therefore, 25 percent increase per unit.

\section{$2.5 k \bar{o} l$ by $35 k \bar{o} l=87.5$ kuzhi.}

If the original measurement rod measured 16 spans, the new one would be 20 spans or if the original specimen was 8 spans or feet in length, the new rod would be 10 spans or feet. This case proves that the land measurement was done different scales and for the conversion of the land from one measurement system to another, they just used arithmetic calculation.

\subsection{Madakku: Reduction of Area}

In the medieval period, several measurement rods were used and sometimes the areas were reduced for taxing 
purpose using simple calculations and they are mentioned as tarmittu madakki [17-19].

An inscription from Vaidyanāta Temple at Tirumazhavādi [16] issued in the $26^{\text {th }}$ year of Rājadhirāja mentions about the land calculation and its conversion. The two measurement units are compared here; however, it may not be accurate, and could be only assumption, since the definition of véli, $m \bar{a}$ and the size of the measurement rods varied greatly. Hence if we do not know all the parameters, proper comparison is not possible. However, an attempt is made here assuming the véli units in the two schemes discussed here are same.

A. The original size of the land is mentioned as:

iraṇdéi mukkālé orumā varaikkāṇi munttirikaik kīzh mukkāl

2 3̌/, 1 mā,ō kāni, muntirikaik kīzh mukkāl

$23 / 4$ véli $+1 m \bar{a}=$

$23 / 4 \times 20=55+1=56 m \bar{a}+$

$\bar{o}$ kāni (1/160) muñtirikaik kīzh mukkāl

$(1 / 320+3 / 4 \times 1 / 320)$

$1 / 160+1 / 320+3 / 1280$

$56 m \bar{a}+1 / 160+1 / 320+3 / 1280$

$56 / 20+1 / 160++1 / 320+3 / 1280$

$3584+8+4+3 / 1280=3599 / 1280=$

$23 / 4=3520+79 / 1280$

\section{B. After Reduction}

The land that originally had 3599/1280 was reduced (taramițtu madakki)

After reduction, it became,

Onpatumā araikkāni muñtirikaik kīzh mukkāle mummāvarai araikkāni

$9 m \bar{a}+1 / 160+1 / 320+1 / 320(3 / 4+3.5 / 20+1 / 160)$

$1 / 320+1 / 320(3 / 4+3.5 / 20+1 / 160)=$

$1 / 320+1 / 320 \mathrm{x}(3 / 4 \times 3 / 20+1 / 40+1 / 160)$

$1 / 320+1 / 320 \times(120+24+4+1 / 160)=149 / 160$

$1 / 320+1 / 320 \times 149 / 160$

$=1 / 320+149 / 51200$

$=160+149 / 51200=309 / 51200$

9 mā+1/160+309/51200

$9 / 20+1 / 160+309 / 51200$

$23040+320+309 / 51200=23669 / 51200$

\section{Comparing $A$ and $B$}

For comparison, A can be converted into

$=3599 / 1280 \times 40 / 40=143960 / 51200$

A) $143960 / 51200$ and B) $23669 / 51200$

Now it is clear that after reduction, A becomes 6.0822 times smaller, assuming the size of the véli is same; however, they must have been different, since the ratio of 6.0822 does not seem to conform to the traditional fraction units, and hence, more research is necessary.

\section{Calculation of Half of an area}

Another calculation in the above mentioned inscription is about the half of the reduced area (see, B After Reduction), which is called "sempāti.'

The original area is:

Onpatumā araikkāṇi muñtirikaik kizh mukkāle mumāvarai araikkāni

$9 m \bar{a}+1 / 160+1 / 320(3 / 4+3.5 / 20+1 / 160)$

According to the inscription, half of the above is

4.5 mā+ muñtirikaik kīzh mukkāle nāningumākkāṇi muntirikai

In the above case, the reduction by half of $9 m \bar{a}$ and araikkāni is clear, and the result is $4.5 m \bar{a}+1 / 320$.

Now let us check, if they have reduced muntirikaik kīzh mukkāle mummāvarai araikkāni properly into two halves.

munttirikaik kīzh mukkāle mummāvarai araikkani=

$1 / 320+1 / 320 \times(3 / 4 \times 3 / 20+1 / 40+1 / 160)$

$1 / 320+1 / 320 \times(120+24+4+1 / 160)=149 / 160$

$1 / 320+1 / 320 \times 149 / 160$

$1 / 320+149 / 51200$

$160+149 / 51200$

$=309 / 51200$

Half of $309 / 51200$, according to the inscription is

=kīzh mukkāle nañgumākkāni muñtirikai.

$1 / 320 x(3 / 4+4 / 20+1 / 80+1 / 320)$

$1 / 320 \times(240+64+4+1 / 320)$

$1 / 320 \times 309 / 320$

$=309 / 102400$

The result of the above division is perfect, which proves the accuracy of the calculation of fractions during the medieval period, i.e. from the Chola times.

\section{Discussion}

Reference to large numbers is found in the Sangam texts. The Sangam Chola king Karikālan is said to have given $16,00,000$ coins to KatiyalÂr urutirankaṇnanār, the poet who composed the text Pattinappālai. The inscriptions provide the details of fractions and their calculation very minutely. The conception of large numbers are more notional, one can reach large numbers just by repeating a large number, for example, kōti kōti kōti kōti. However, 
the story found in the work Lalitavistära about Buddha's learning related to mathematics does prove that the large numbers were taught to students [13]. There are many theories on the origin of the place value system and one suggests that it came up in India $[6,13]$; but, these questions are not easy to address, as borrowing of ideas and movement of people and knowledge were happening in the early historic period, although historians sometimes tend to underestimate such contacts and interaction. However, more critical study is required on these aspects; but it would not be a surprise if this idea had evolved in India, considering the variety of developments in the medieval period.

The medieval measurement units such as $m \bar{a}$ and véli units were not uniform in size and their area varied, according to the size of the measurement rod. Hence, the area units based on one measurement system cannot be directly compared to another system, without going into the various parameters involved.

From about tenth century CE, we do notice very fine, minute arithmetic calculations in the inscriptions. The terms such as madakku and virivu reveal the various operations related to land assessment. The medieval records of land and taxes were properly maintained in order to collect and manage tax revenue systematically. When they converted the land areas, which were based on smaller scale (measurement rod) to a larger scale, minute fractions resulted. These fractions and numerals could be used to improve the cognitive skills of the students in contemporary education. Detailed research is needed for understanding the emergence of numbers and fractions in the Tamil region.

\section{References}

1. Bag, A.K. Mathematics in Ancient and Medieval India. Varanasi: 1979.

2. Bhagavathy, K. Tamizhar Alavaikal. Chennai: International Institute of Tamil Studies, 2003.

3. Bharathiyar, C. Iniyia Thamizh Ilakkanam. Chennai: Kavitha Publications. Available http://tamilelibrary.org/teli/numeral. html (accessed on 1 June 2016).

4. Danino. Landmarks of Science in Early India. 2009. Available www.iisc.ernet.in/prasthu/pages/PP_data/105.pdf (accessed on 1 June 2016).

5. Jagadish, A. \& Rajaram, H. Text and practices: Land measure in South India, with special reference to Karnataka. Seminar SAW: History of Mathematics, History of Economical and
Financial Practices. Land registers and surveyors: Measuring lengths and areas. 2012.

6. Joseph, G.G. The crest of the peacock. Princeton: Princeton University Press, 2011.

7. Karashima, N. Kîl in the Description of Land-extent in Chola Inscriptions: Effort to Build a Centralized State by Rajaraja I. AdhAram, vol. 1, pp. 45-48, 2006.

8. Nayanar, K. Kanakkatikaram. Chennai: Thirunelveli Saiva Sidhanta book Publication Society, 1958.

9. Mahadevan, I. Early Tamil Epigraphy. The Earliest Times To The Sixth Century A.D. U S A and Chennai: Cre-A, Harvard Oriental Series, Harvard University, 2003.

10. Gandhi, M.S. \& Ramachandran, M. Papanasam Vattakkalvettukal. Vol. 1. Chennai: Tamil Nadu State Archaeology Department, 2004.

11. Mini, P.M. Contribution of Jainas to mathematics with special reference to Ganitasarasangraha of Mahavira [PhD. Dissertation], MG University, Kottayam: UC College, Aluva, Kerala, 2014.

12. Muthukumar. Ancient Tamil Units. 2014. Available: http:// tmuthukumar.blogspot.in/2014/06/ancient-tamil-units.html

13. O’Connor, J.J. \& Robertson, E.F. Indian numerals. 2000. Available: http://www-history.mcs.st-andrews.ac.uk/ HistTopics/Indian_numerals.html

14. Shanmugam, P. The Revenue System of the Cholas 850-1279. Madras: New Era Publications, 1987.

15. Shanmugan, K.S. Pazhanthamizhar Poriyiyal Nutpattiran. Chennai: Meenagopal Pathippakam, 2006.

16. SII= South Indian Inscriptions, New Delhi: Archaeological Survey of India.

17. Subbarayalu, Y. Land Measurement in Medieval Tamil Nadu. In Rajagopal (Ed.). Kaveri: Studies in Epigraphy, Archaeology and History. Chennai: Panpattu Veliyittakam, 2001a. pp. 31-40.

18. Subbarayalu, Y. Classification of Land and Assessment of Land tax. In Rajagopal (Ed.). Kaveri: Studies in Epigraphy, Archaeology and History. Chennai: Panpattu Veliyittakam, 2001b. pp. 53-59.

19. Subbarayalu, Y. Quantifying Land Revenue Assessment of the Chola State. In Rajagopal (Ed.). Kaveri: Studies in Epigraphy, Archaeology and History. Chennai: Panpattu Veliyittakam, 2001c. pp. 65-81.

20. Subrahmanian, N. Pre-Pallavan Tamil Index. Madras: Madras University. 1966.

21. Sykorova, I. Fractions in Ancient Indian Mathematics. WDS'10 Proceedings of Contributed Papers, Part I, 2010. pp. 133-138.

22. TVA 2014. Tamil Fractions and Symbols - Amendment Proposal. Government of Tamilnadu, India.

23. Venkayya, V. South Indian Inscriptions vol II, part IV. Madras: Archaeological Survey of India, 1913. 